\title{
A novel bacteriocin produced by Lactobacillus plantarum LpU4 as a valuable candidate for biopreservation in artisanal raw milk cheese
}

\author{
C. Milioni ${ }^{1,3}$ - B. Martínez ${ }^{2}$ S. Degl'Innocenti ${ }^{3}$.

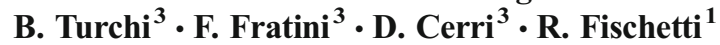

Received: 10 November 2014 / Revised: 7 April 2015 / Accepted: 10 April 2015 /

Published online: 22 May 2015

(C) INRA and Springer-Verlag France 2015

\begin{abstract}
Indigenous lactic acid bacteria-producing bacteriocins could enhance the microbiological safety of traditional cheeses. This study aimed to detect bacteriocinogenic strains among 35 Lactobacillus plantarum isolated from artisanal, raw sheep-milk cheeses. The isolates were identified by API 50 CHL and speciesspecific PCR. As displayed by agar well-diffusion assay, the cell-free supernatant of L. plantarum LpU4 showed the highest antimicrobial activity against Enterococcus faecalis $\mathrm{JH} 2-2$. The activity was not detected after treatment with proteinase $\mathrm{K}$, pepsine and pronase. An active peptide band was shown by tricine-sodium dodecyl sulfate (SDS)-polyacrylamide gel electrophoresis and subsequent bioassay. MALDI-TOF analysis revealed a protein of 4,866.7 $\mathrm{Da}$, having no homology with other known bacteriocins. The novel bacteriocin (named plantaricin LpU4) was heat stable $\left(121{ }^{\circ} \mathrm{C}\right.$ for $15 \mathrm{~min}$ ), unaffected by chemicals as Tween 20 , SDS, Triton $\times 100, \mathrm{EDTA}, \mathrm{NaCl}$ and exposure to a wide range of $\mathrm{pH}$. The synthetic machinery encoding for the plantaricin was plasmid-located, as deduced by plasmids curing. Activity spectrum included several lactic acid bacteria and Staphylococcus aureus strains having antibiotic resistance phenotype. Plantaricin LpU4 showed a bacteriostatic mode of action and an enhanced activity at acidic pHs. Maximal production $\left(3,200 \mathrm{AU} \cdot \mathrm{mL}^{-1}\right)$ was reached during the late exponential phase of growth of $L$. plantarum LpU4. Relatively low temperature $\left(15-25^{\circ} \mathrm{C}\right)$ and initial $\mathrm{pH}$ between 5.5 and 6.2 increased the production. Since L. plantarum LpU4 produced the bacteriocin under experimental conditions
\end{abstract}

\footnotetext{
C. Milioni

carla.milioni@izslt.it
}

1 IZSLT, Istituto Zooprofilattico Sperimentale Lazio e Toscana, SS Abetone e Brennero 4, 56100 Pisa, Italy

2 Consejo Superior de Investigaciones Científicas, IPLA-CSIC, Instituto de Productos Lácteos de Asturias, Paseo Río Linares s/n, 33300 Villaviciosa, Asturias, Spain

3 Dipartimento di Scienze Veterinarie, Università di Pisa, Viale delle Piagge 4, 56100 Pisa, Italy 
mimicking the cheese environment, it could be considered a promising candidate for use as biopreservative in traditional cheese.

Keywords Lactobacillus plantarum - Bacteriocin - Biopreservation · Traditional cheese Staphylococcus aureus

\section{Introduction}

In recent years, a consumers' study reported a general good attitude toward the consumption of traditional food positively associated with characteristic taste, quality, healthiness and safety (Almli et al. 2011). Raw milk cheeses produced in a limited area, using traditional knowledge handed down over generation, are rightfully included in the definition of traditional food (Montel et al. 2014). One of the main challenges in traditional food production is assuring food safety while satisfying the consumer's demand of products with natural content and free of chemical preservatives (Pieniak et al. 2009). During the fermentation step of cheese making, lactic acid bacteria (LAB) inhibit many pathogenic and spoilage microorganisms. Antagonism is primarily attributed to growth competition and production of organic acids, in addition, many LAB strains synthesize other antimicrobial compounds such as bacteriocins, which increase their protective role.

Bacteriocins from LAB are described as ribosomally synthesized proteins or protein complexes frequently antagonistic to genetically related Gram-positive bacteria (De Vuyst and Leroy 2007). Due to their proteinaceous nature, bacteriocins are presumptively safe to humans because they can be degraded in the gastrointestinal tract. Based on their chemical structure and functional properties, bacteriocins have been classified by Cotter et al. (2005) into two major classes. Class I consists of lantibiotics, small $(<5 \mathrm{kDa})$ heat stable peptides which are extensively modified after translation resulting in characteristic amino-acids, such as lanthionine and derivatives. Class II includes small $(<10 \mathrm{kDa})$, heat stable, non-lanthionine containing peptides, divided in subclass IIa (pediocin-like bacteriocins active against Listeria spp.), IIb (bacteriocins composed of two separate peptides working synergistically to have antimicrobial activity), IIc (cyclic bacteriocins) and IId (single peptide, non-pediocin-like, linear bacteriocins). Several bacteriocins from cheese-isolated Lactobacillus plantarum strains have been characterized in the past (Hernández et al. 2005; Mills et al. 2011; Martinez et al. 2013). Occurrence of non-starter L. plantarum in cheese microbiota appears to be a common trait of a variety of raw milk cheeses (Golic et al. 2013; De Pasquale et al. 2014; Caro et al. 2013). Non-starter LAB can arise not only from milk, but also from other indirect sources as feed, traditional equipment or practices as reviewed by Montel et al. (2014). These wild $L$. plantarum can be a valuable source of strains with potential technological application as biopreservatives. In fact, a high percentage of L. plantarum strains isolated from a farmhouse cheese (Lavilla-Lerma et al. 2013) and Oaxaca cheese (Caro et al. 2013) have been reported to produce bacteriocins or bacteriocin-like substances.

This study aimed to detect bacteriocinogenic strains among L. plantarum strains isolated from traditional raw milk Italian "Pecorino" cheeses and to characterize a novel bacteriocin (named plantaricin LpU4) produced by the selected L. plantarum LpU4. We investigated the activity spectrum, biochemical characteristics, molecular mass, 
kinetics of growth, mode of action, conditions affecting the in vitro production and location of the synthetic machinery of plantaricin LpU4.

\section{Materials and methods}

\subsection{Bacterial strains and growth conditions}

Thirty-five L. plantarum isolates, previously identified by phenotypic assay (API 50 CHL, Biomerieux, France) and species-specific PCR (Torriani et al. 2001), were screened for bacteriocin production. The origin of the strains is reported in Table 1. Before the experiments, the strains were propagated twice in MRS broth (Pronadisa, Madrid, Spain) at $30{ }^{\circ} \mathrm{C}$ for $24 \mathrm{~h}$, then stationary phase cultures were inoculated $(1 \%$ $v / v)$ in fresh MRS and incubated at $25^{\circ} \mathrm{C}$ for $24 \mathrm{~h}$.

Microorganisms listed in Table 2 were used to evaluate the activity spectrum. The strains were grown up to the middle exponential phase in appropriate liquid medium and then variable volumes were inoculated in the corresponding agar medium (adjusted to $\mathrm{pH}$ 6) in order to reach a final concentration of around $10^{6} \mathrm{CFU} \cdot \mathrm{mL}^{-1}$.

\subsection{Bacteriocin activity assays}

Cell-free supernatant (CFS) was obtained removing bacterial cells by centrifugation $(9,000 \times g$ for $15 \mathrm{~min})$, then the samples were adjusted with $\mathrm{NaOH} 5 \mathrm{~mol} . \mathrm{L}^{-1}$ to the same $\mathrm{pH}$ recorded in the cheese matrix at the isolation time (Table 1). After filtration throughout a 0.20 - $\mu \mathrm{m}$-pore size membrane (Sartorius-Stedim), the antimicrobial activity of the isolates was primarily investigated against Enterococcus faecalis $\mathrm{JH} 2-2$ by agar well-diffusion assay: briefly, 8-mm-diameter wells were cut in inoculated BHI agar $(1.2 \% w / v)$ and $100 \mu \mathrm{L}$ of CFS were added. After $24 \mathrm{~h}$ of pre-incubation at $4{ }^{\circ} \mathrm{C}$, the plates were incubated at $37{ }^{\circ} \mathrm{C}$ and the diameter of halo around the wells was measured. The strain showing the wider inhibition halo (named L. plantarum LpU4) was selected for further investigation. Agar well-diffusion assay was performed to evaluate the L. plantarum LpU4 activity spectrum: culture media and incubation temperature for each target microorganism are reported in Table 2.

Moreover, activity titre was determined by spot-on-the-lawn method (Van Reenen et al. 1998) and expressed as Arbitrary Units per milliliter (AU.mL ${ }^{-1}$ ).

\subsection{Characterization of the antimicrobial activity}

Residual activity in L. plantarum LpU4 CFS was evaluated after treatments with catalase (Parchem, USA), proteolytic enzymes, chemicals and exposition to a wide range of $\mathrm{pH}$ and temperature (Table 3 ). Untreated CFS was included in each experiment as control.

\subsection{Plasmid curing}

Plasmidic profile of L. plantarum LpU4 was determined according to O'Sullivan and Klaenhammer (1993). Plasmid curing was carried out by repeated inoculations in MRS 
Table 1 Characteristics of the isolates tested for antimicrobial activity production; $\mathrm{pH}$ range indicates the minimum and maximum value recorded in the different "Pecorino" cheeses in regard to the ripening days

\begin{tabular}{|c|c|c|c|}
\hline Strain & $\begin{array}{l}\text { Geographical } \\
\text { origin of cheese }\end{array}$ & $\begin{array}{l}\text { Day of ripening } \\
\text { at the isolation } \\
\text { time }\end{array}$ & $\begin{array}{l}\mathrm{pH} \text { of the } \\
\text { cheese } \\
\text { matrix }\end{array}$ \\
\hline LpU2 & Siena & 60 & 5.8 \\
\hline LpU3 & Siena & 45 & $5.0-5.7$ \\
\hline LpU4 & Siena & 7 & $4.8-5.6$ \\
\hline LpU5 & Siena & 28 & $4.9-5.6$ \\
\hline LpU6 & Siena & 60 & 5.8 \\
\hline LpU7 & Pisa area & 28 & $4.9-5.6$ \\
\hline LpU8 & Pisa area & 7 & $4.8-5.6$ \\
\hline LpU9 & Pisa area & 14 & $4.5-5.6$ \\
\hline LpU10 & Pisa area & 7 & $4.8-5.6$ \\
\hline LpU11 & Lunigiana & 28 & $4.9-5.6$ \\
\hline LpU12 & Lunigiana & 28 & $4.9-5.6$ \\
\hline LpU13 & Lunigiana & 7 & $4.8-5.6$ \\
\hline LpU14 & Lunigiana & 7 & $4.8-5.6$ \\
\hline LpU15 & Lunigiana & 14 & $4.5-5.6$ \\
\hline LpU16 & Lunigiana & 14 & $4.5-5.6$ \\
\hline LpU17 & Lunigiana & 2 & $4.5-5.6$ \\
\hline LpU18 & Pisa & 28 & $4.9-5.6$ \\
\hline LpU19 & Pisa & 28 & $4.9-5.6$ \\
\hline LpU20 & Pisa & 42 & $5.0-5.7$ \\
\hline LpU21 & Pisa & 42 & $5.0-5.7$ \\
\hline LpU22 & Pisa & 42 & $5.0-5.7$ \\
\hline LpU23 & Pisa & 42 & $5.0-5.7$ \\
\hline LpU24 & Pisa & 42 & $5.0-5.7$ \\
\hline LpU25 & Pisa & 42 & $5.0-5.7$ \\
\hline LpU26 & Pisa area & 60 & 5.8 \\
\hline LpU27 & Pisa area & 60 & 5.8 \\
\hline LpU28 & Pisa area & 60 & 5.8 \\
\hline LpU29 & Pisa area & 60 & 5.8 \\
\hline LpU30 & Pisa area & 2 & $4.4-5.5$ \\
\hline LpU31 & Pisa area & 2 & $4.4-5.5$ \\
\hline LpU32 & Pisa area & 2 & $4.4-5.5$ \\
\hline LpU33 & Pisa area & 7 & $4.9-5.6$ \\
\hline LpU34 & Pisa area & 7 & $4.9-5.6$ \\
\hline LpU35 & Pisa area & 28 & $4.9-5.6$ \\
\hline LpU36 & Pisa area & 28 & $4.9-5.6$ \\
\hline
\end{tabular}

broth added with novobiocin (1.5\% w/v) as described by Ruiz-Barba et al. (1991). After curing, isolate colonies unable to inhibit $E$. faecalis $\mathrm{JH} 2-2$ were selected and plasmidic profile of a bacteriocin-deficient derivative (named L. plantarum LpU4p) was evaluated. Loss of self-immunity in L. plantarum LpU4p was tested by agar well-diffusion 


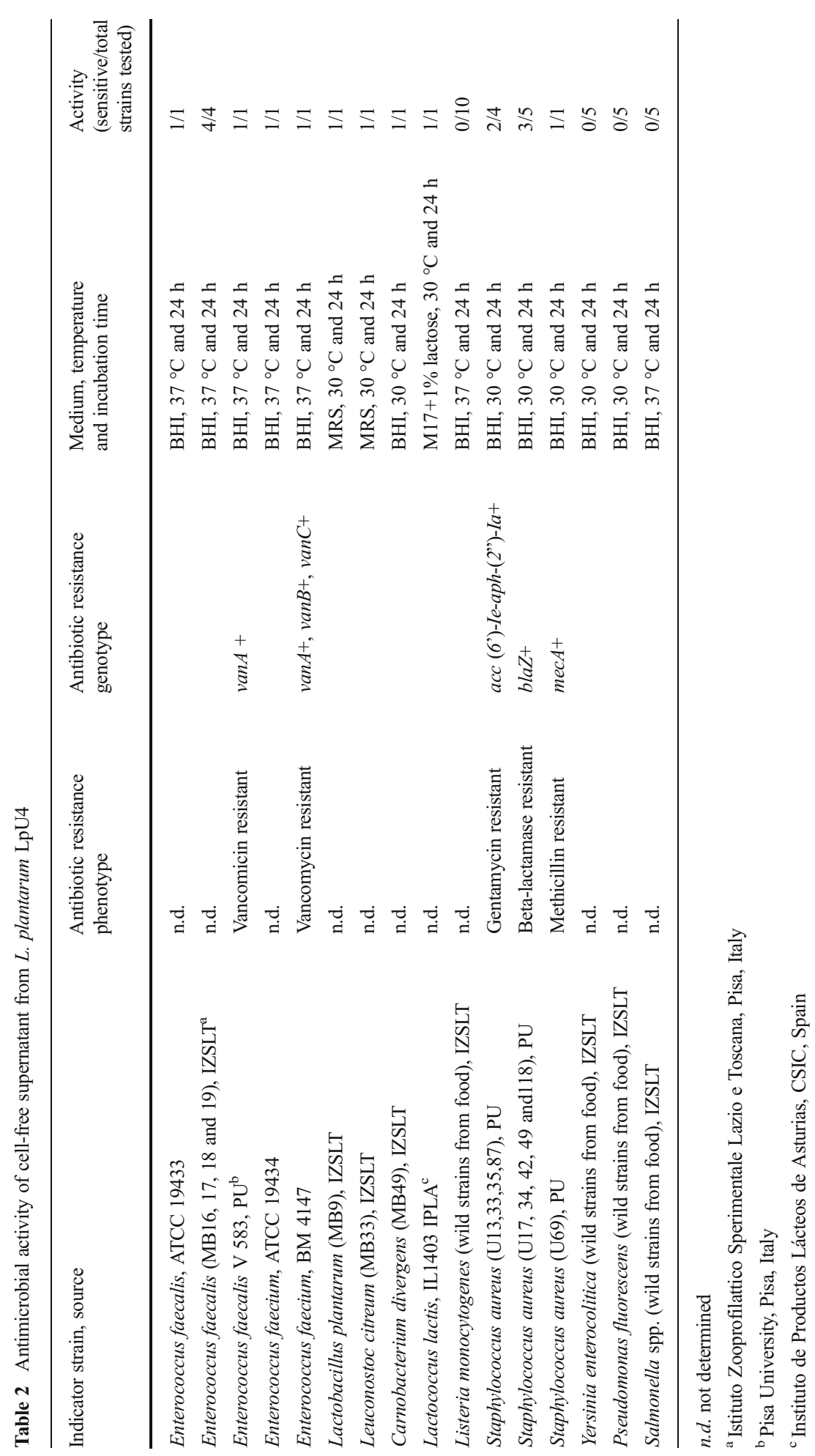


Table 3 Preliminary characterization of the antimicrobial activity of L. plantarum LpU4

\begin{tabular}{lll}
\hline Treatment & Conditions & $\begin{array}{l}\text { Percentage of } \\
\text { residual activity }\end{array}$ \\
\hline Catalase & & 100 \\
Proteases & & \\
$\quad$ Proteinase K, pepsine and pronase & $1 \mathrm{mg} \cdot \mathrm{mL}^{-1}, 1 \mathrm{~h}$ and $37^{\circ} \mathrm{C}$ & 0 \\
Chemicals & & \\
$\quad$ Tween 20, SDS, Triton $\times 100$, EDTA and $\mathrm{NaCl}$ & $1 \%, 5 \mathrm{~h}$ and $37{ }^{\circ} \mathrm{C}$ & 100 \\
pH (2-12) & $2 \mathrm{~h}$ and $37{ }^{\circ} \mathrm{C}$ & 100 \\
$\quad$ Temperature & $37,50,70$ and $100{ }^{\circ} \mathrm{C}, 1 \mathrm{~h}$ & 100 \\
Autoclaving & $121{ }^{\circ} \mathrm{C}$ and $15 \mathrm{~min}$ & 87 \\
\hline
\end{tabular}

${ }^{a}$ Residual activity referred to untreated cell-free supernatant

assay using this strain as target for L. plantarum LpU4 CFS. In addition, the fermentative profile of this $\mathrm{Bac}(-)$ derivative was evaluated.

\subsection{Tricine-SDS-PAGE and bioassay}

Proteins in L. plantarum LpU4 and L. plantarum LpU4p CFS (2 mL) were concentrated adding $120 \mu \mathrm{L}$ of trichloroacetic acid. After overnight incubation at $-20^{\circ} \mathrm{C}$, the samples were centrifuged $\left(16,000 \times g, 4{ }^{\circ} \mathrm{C}\right)$, the pellet was washed with $500 \mu \mathrm{L}$ of acetone and dried at $60{ }^{\circ} \mathrm{C}$.

Pellet was resuspended in $30 \mu \mathrm{L}$ of $100 \mathrm{mmol}^{-1} \mathrm{~L}^{-1}$ sodium phosphate buffer, $\mathrm{pH} 6.8$. After separation by tricine-sodium dodecyl sulfate-polyacrylamide gel electrophoresis (SDS-PAGE) as described by Schagger and Von Jagow (1987), one half of the gel was stained with Comassie Blue and one half was used for the bioassay as described by Todorov et al. (2011).

\subsection{Mass spectrometry}

The protein band showing antimicrobial activity was excised from the tricine-SDSPAGE gel, digested with porcine trypsin (Promega, Madison, WI, USA), and the resulting peptides were analysed by MALDI-TOF mass spectrometry at the proteomic facility of Inbiotec (León, Spain). The molecular mass of the undigested protein was determined as previously described (Cohen and Chait 1997).

\subsection{Growth kinetics and antimicrobial activity}

L. plantarum LpU4 was inoculated in MRS broth and incubated at $25^{\circ} \mathrm{C}$ for $48 \mathrm{~h}$. In a separate experiment, the strain was cultured in a modified MRS broth at $\mathrm{pH} 5.8$ (MRS 5) adding citric acid and sodium citrate (Carlo Erba Reagenti, Milano, Italy) to the standard formula in order to obtain a citrate buffer according to Gomori (1946). At time intervals, changes in pH, optical density (OD; Genesis $10 \mathrm{UV}$, ThermoScientific) and antimicrobial activity were recorded. Growth parameters (maximum rate and final cell 
density) were estimated by DMFit software (Web version-Institute of Food Research, Norwich, UK) using OD values.

\subsection{Mode of action}

Active growing cells of E. faecalis JH2-2 were inoculated in $1 \mathrm{~mL}$ of MRS broth and $50 \mu \mathrm{L}$ of TCA-precipitated proteins from L. plantarum LpU4 CFS (80 AU of plantaricin LpU4) were added after $90 \mathrm{~min}$ of incubation at $37{ }^{\circ} \mathrm{C}$. As control, TCA-precipitated proteins from CFS of L. plantarum LpU4p were used. Experiments were performed in triplicate, and OD $(600 \mathrm{~nm})$ was recorded at time intervals up to $270 \mathrm{~min}$ of growth. Count of viable cells was performed by $3 \mathrm{M}^{\mathrm{TM}}$ Petrifilm ${ }^{\mathrm{TM}} \mathrm{AC}(3 \mathrm{M}, \mathrm{USA})$ at the beginning and the end of the experiment. In a separate experiment, crude plantaricin $\left(800 \mathrm{AU} \cdot \mathrm{mL}^{-1}\right)$ was added at the beginning of the incubation and the OD was recorded until $24 \mathrm{~h}$.

\subsection{Factor affecting bacteriocin activity and production}

Effect of $\mathrm{pH}$ on antimicrobial activity of the bacteriocin LpU4 was investigated: aliquots of CFS were adjusted at $\mathrm{pH}$ ranging from 4 to 7 and relative antimicrobial activity (compared to $\mathrm{pH} \mathrm{5)} \mathrm{was} \mathrm{evaluated} \mathrm{by} \mathrm{agar} \mathrm{well-diffusion} \mathrm{assay.} \mathrm{To} \mathrm{estimate}$ putative antimicrobial effect by non-dissociated organic acids, CFS from L. plantarum LpU4p (grown under the same culture conditions) was adjusted to the same $\mathrm{pH}$ values and was used as negative control.

Moreover, some factors affecting the bacteriocin production were investigated: the inoculum size $(0.1,1$ and $5 \% v / v)$ during the L. plantarum LpU4 growth in MRS broth at $25^{\circ} \mathrm{C}$; the temperature of incubation $\left(15,20,25,30\right.$ and $\left.37^{\circ} \mathrm{C}\right)$ during the growth in MRS broth and $1 \% v / v$ of inoculum; the initial $\mathrm{pH}$ of medium $(5,5.5$ and 6.2$)$ during the growth at $25{ }^{\circ} \mathrm{C}$ and $1 \% v / v$ of inoculum. Experiments were done in triplicate, and the diameter of inhibition zone was measured by callipers. The results were analysed statistically by applying a one-way ANOVA test and a post-hoc Tukey's test $(P \leq 0.05)$ for mean comparison. Analysis was performed using Co-Stat 6.4 software (CoHort Software, Monterey, USA).

\section{Results}

\subsection{Isolation of the antagonistic strain L. plantarum LpU4 and activity spectrum}

Five out of 35 CFS from L. plantarum strains inhibited the growth of E. faecalis JH2-2 (data not shown). Host range of the selected L. plantarum LpU4 included milk-isolated Staphylococcus aureus strains with various resistance phenotypes (Table 2). Also, several food-isolated lactic acid bacteria were sensitive. No inhibition was recorded against Listeria monocytogenes and the tested Gram-negative bacteria.

\subsection{L. plantarum LpU4 is a bacteriocin producer}

Complete loss of activity after treatment with proteolytic enzymes revealed the proteinaceous nature of antimicrobial activity in the CFS of L. plantarum LpU4. 
Involvement of $\mathrm{H}_{2} \mathrm{O}_{2}$ was excluded as the activity was still detected after the treatment with catalase. Activity was not affected by anionic detergents (Tween 20 and SDS), non-ionic surfactants (Triton $\times 100$ ) and salts (EDTA and $\mathrm{NaCl}$ ). It was also stable after incubation at wide range of $\mathrm{pH}$ and temperature (Table 3). Tricine-SDS-PAGE and subsequent bioassay revealed the presence of a peptide band retaining antimicrobial activity against $E$. faecalis JH2-2 (Fig. 1). The molecular mass, determined by MALDIMS, was 4,866.7 Da. Tryptic peptide mass fingerprints did not match any previously described bacteriocins or other proteins deposited in the databases. This novel bacteriocin was named plantaricin LpU4.

\subsection{Plantaricin LpU4 is plasmid-encoded}

After nine consecutive passages in novobiocin, one isolated colony from L. plantarum LpU4 lost the ability to inhibit the growth of E. faecalis JH2-2 and became sensitive to LpU4 plantaricin. As shown in Fig. 2, several DNA bands ranging from 95 to $8 \mathrm{kbp}$ were detected in L. plantarum LpU4. Although it is difficult to determine the precise number of plasmids in this strain, all of them with the exception of an 8-kbp plasmid were apparently lost after curing. According to these results, bacteriocin production and immunity in L. plantarum LpU4 must be encoded by one of the high molecular size plasmids. Further confirmation that LpU4 bacteriocin is plasmid encoded was provided by the absence of the antimicrobial peptide in concentrated CFS from the cured L. plantarum LpU4p (Fig. 1). Since no change in fermentative profile of bacteriocin-deficient derivative was recorded, no correlation could be established between bacteriocin production and sugar utilization.

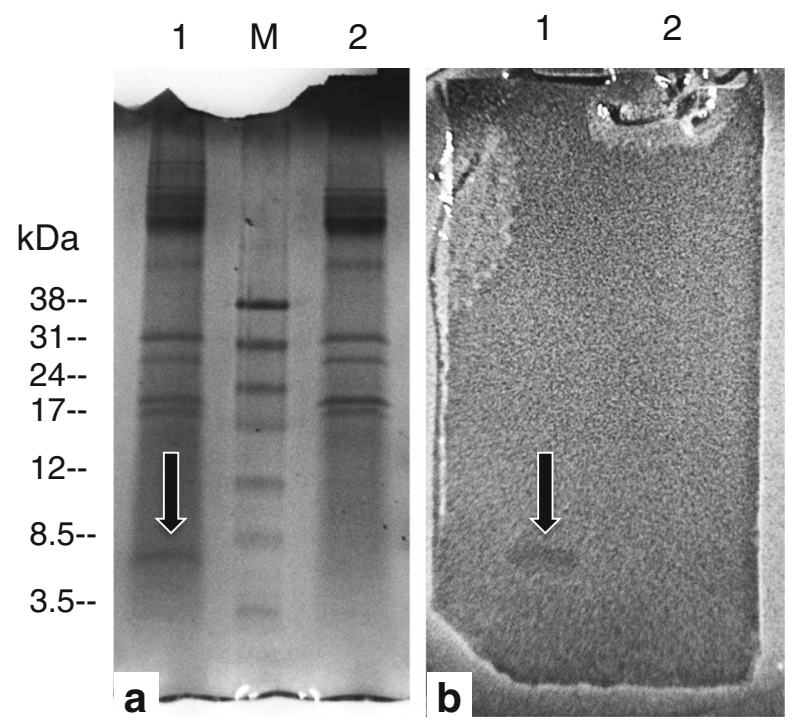

Fig. 1 Detection of the bacteriocin produced by L. plantarum LpU4. a Tricine-SDS-PAGE of concentrated supernatants of L. plantarum LpU4 (1) and from its non-bacteriocin derivative L. plantarum LpU4p (2). M molecular weight markers $(\mathrm{kDa})$. b Gel bioassay overlaid with E. faecalis JH2-2. Arrows indicate the active band and the corresponding inhibition area 


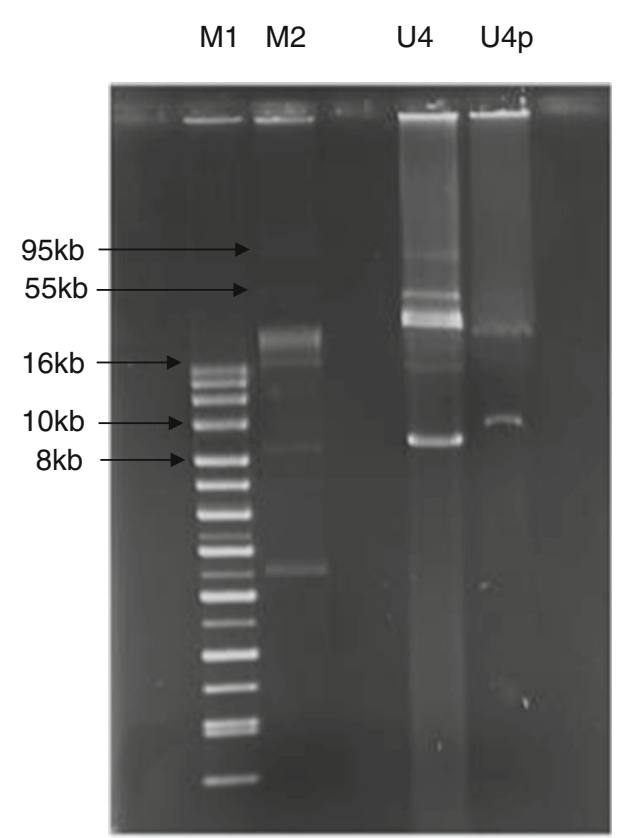

Fig. 2 Plasmid isolation from the bacteriocinogenic strain L. plantarum LpU4 and from its non-bacteriocin derivative (LpU4p). M1 and M2 (kbp) are supercoiled DNA ladder (Invitrogen, Barcelona, Spain) and Bactracker supercoiled DNA ladder (Epicentre Biotechnologies, WI, USA)

\subsection{Kinetics of growth and bacteriocin production}

In MRS broth at $25{ }^{\circ} \mathrm{C}$, the production of antimicrobial activity was recorded at the beginning of the exponential phase; the maximum $\left(1,600 \mathrm{AU} \cdot \mathrm{mL}^{-1}\right)$ was reached when the strain entered the late exponential phase $(24 \mathrm{~h})$ and remained constant during the stationary phase up to $48 \mathrm{~h}$. In MRS 5, activity increased from 100 to 3,200 AU.mL ${ }^{-1}$ during the exponential growth phase and was stable until the end (Fig. 3b). The estimated L. plantarum LpU4 growth rate in MRS was faster than in MRS $5\left(0.51 \pm 0.05\right.$ vs $0.41 \pm 0.04$ OD. $\left.\mathrm{h}^{-1}\right)$, but final cell density was greater in MRS 5 (OD, $8.17 \pm 0.20$ vs $7.43 \pm 0.16)$. In MRS, the $\mathrm{pH}$ decreased to 3.82 after $28 \mathrm{~h}$ and then leveled off; while in MRS 5, acidification was slower, which was likely due to the buffering citrate, and reached 3.89 after $48 \mathrm{~h}$ (Fig. 3a).

\subsection{Mode of action}

Plantaricin LpU4 displayed a bacteriostatic mode of action. As shown in Fig. 4, by adding the bacteriocin, the growth of target microorganism stopped and remained unchanged until the end. The count of viable cells at 90 and $270 \mathrm{~min}$ was unaltered (7.97 \pm 0.03 versus $8.40 \pm 0.33 \log _{10}$ CFU.mL ${ }^{-1}$ ). When crude plantaricin was added at the beginning of the incubation, the bacteriostatic effect was recorded until $24 \mathrm{~h}$ (data not shown). 

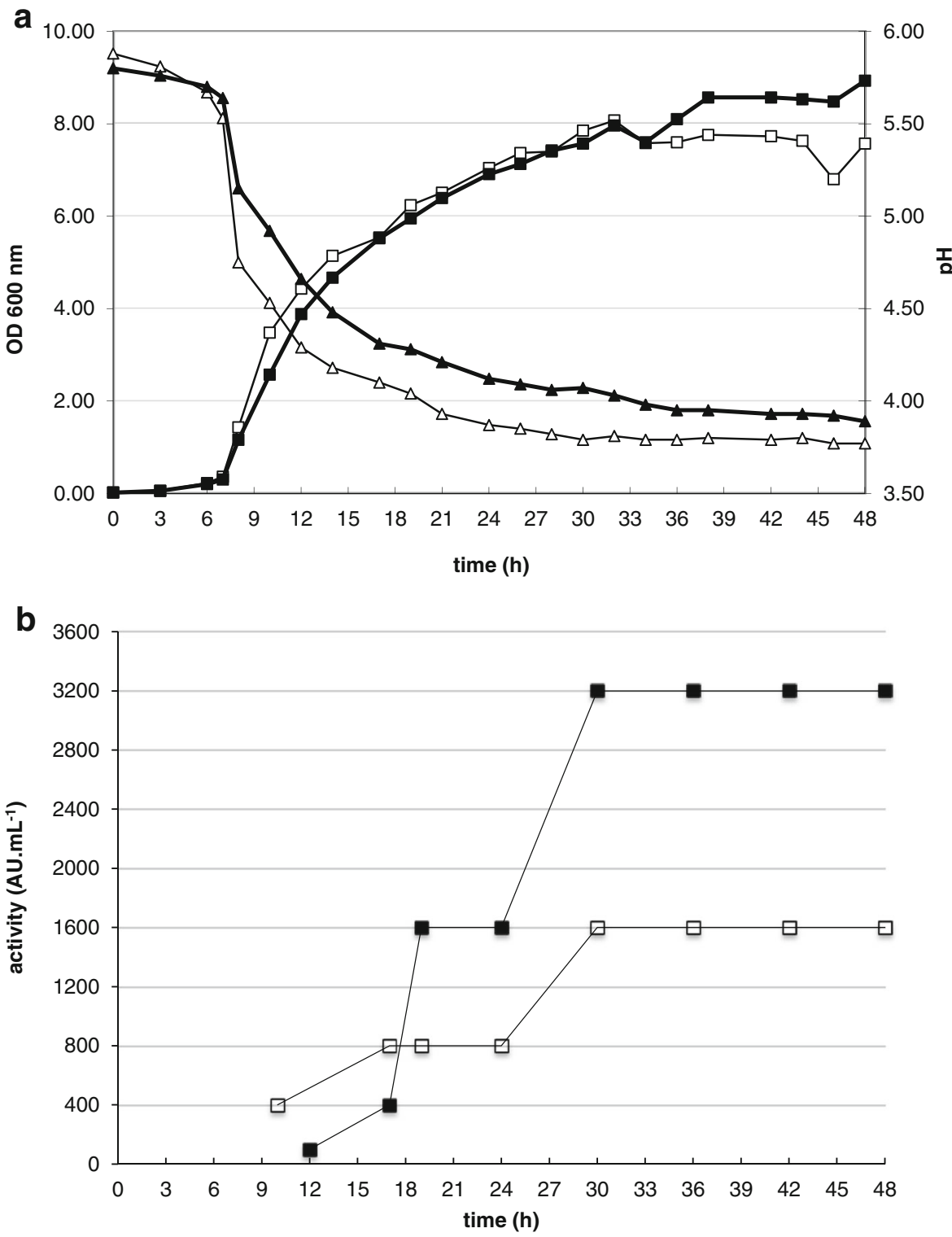

Fig. 3 a Growth of L. plantarum LpU4 in MRS (square) and in citrate-buffered MRS 5 (filled square); changes in $\mathrm{pH}$ in MRS (triangle) and MRS 5 (filled triangle). b Antimicrobial activity (AU.mL ${ }^{-1}$ ) during growth in MRS (square) and MRS 5 (filled square). Standard deviation from three repeats was $<5 \%$ and is not reported

\subsection{Factors affecting the bacteriocin activity and production}

The antimicrobial activity of crude plantaricin LpU4 appeared to be maximal at acidic $\mathrm{pHs}$ and decreased towards more neutral pHs (Fig. 5). An additional antimicrobial effect only due to non-dissociated organic acids was excluded, since no inhibition was showed up to $\mathrm{pH} 4.5$ by the CFS of L. plantarum LpU4p. The 


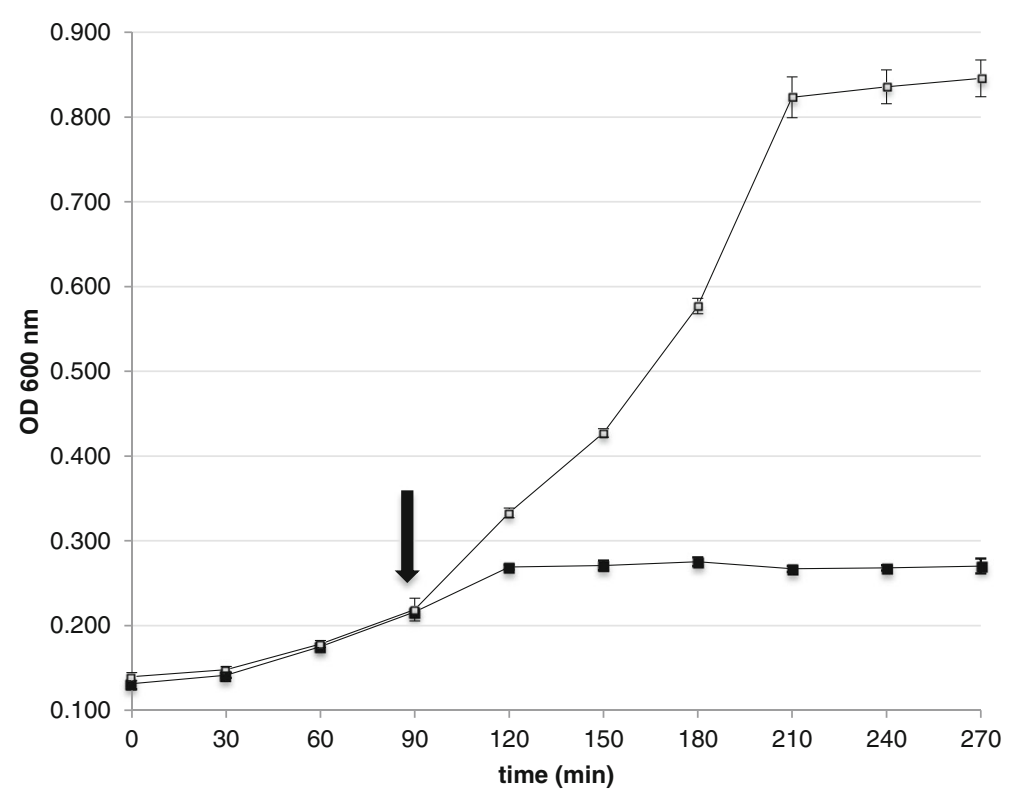

Fig. 4 Effect of plantaricin LpU4 on the growth of E. faecalis JH2-2 (filled square). Control is indicated as (square). Arrow shows when the plantaricin was added (90 min)

bacteriocin production in MRS broth was not influenced by the inoculum size, as shown in Fig. 6a. On the contrary, temperature played an important role: no inhibition was detected at $37{ }^{\circ} \mathrm{C}$ and a statistically significant reduction $(p<0.05)$ was recorded between the maximal production at $30{ }^{\circ} \mathrm{C}$ and at lower temperature $\left(15,20\right.$ and $25^{\circ} \mathrm{C}$; Fig. 6b). Moreover, growth in MRS broth at initial $\mathrm{pH} 5.5$ or 6.2 significantly increased $(p<0.05)$ the activity compared to $\mathrm{pH} 5$ (Fig. 6c).

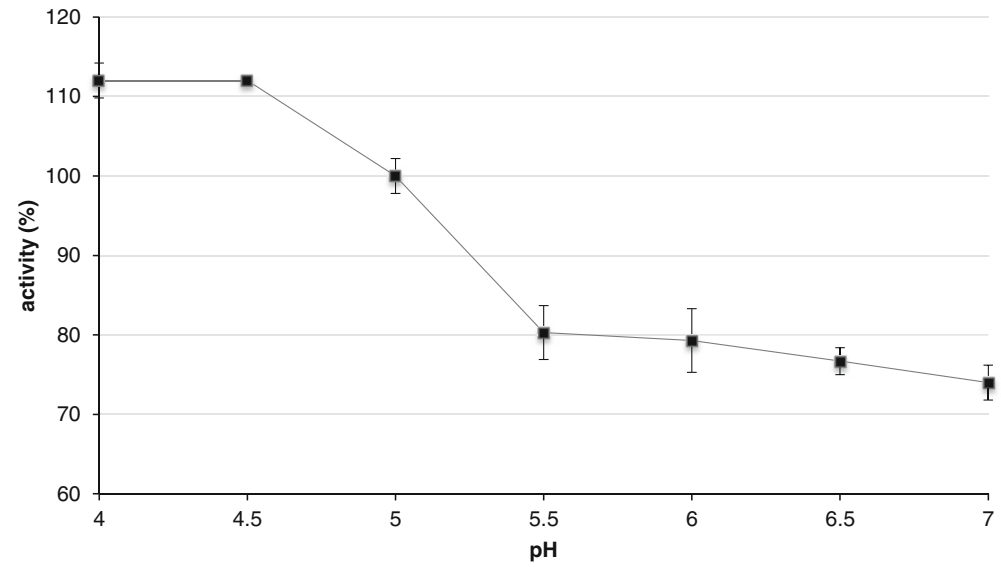

Fig. 5 Activity of plantaricin LpU4 at different $\mathrm{pH}$. Experiments were done in triplicate; percentage of inhibition areas is shown as mean $\pm \mathrm{SD}$ compared with $\mathrm{pH} 5$ 

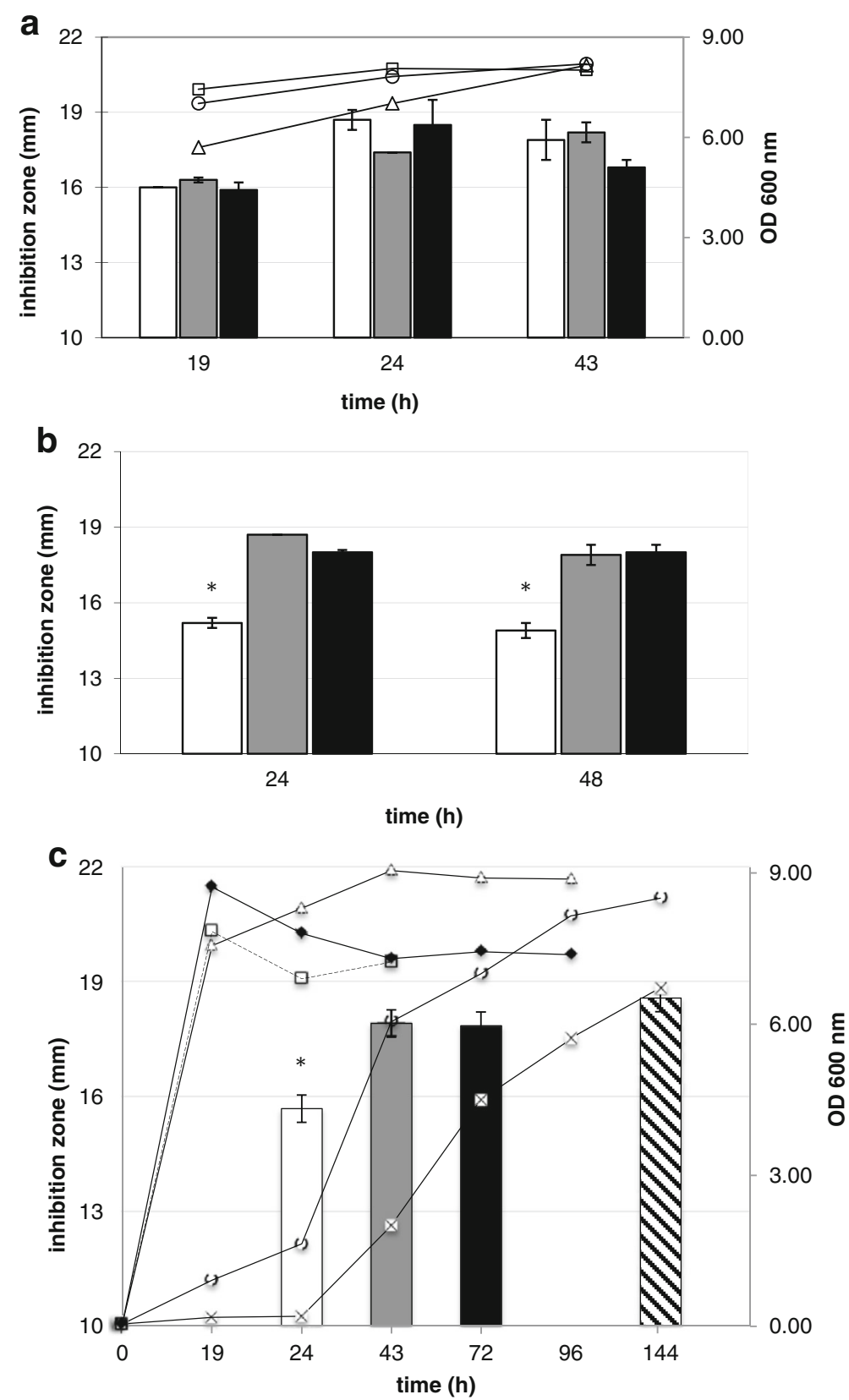

Fig. 6 Bacteriocin production under several cultural conditions: a effect of the inoculum size: 0.1 (blank bars), 1 (grey bars) and 5\% (black bars). Cell growth is shown as triangles $(0.1 \%)$, circles $(1 \%)$ and squares (5\%); b effect of the initial pH: 5 (blank bars), 5.5 (grey bars) and 6.2 (black bars); and c effect of the temperature: $15{ }^{\circ} \mathrm{C}$ (lined bar), 20 (black bar), 25 (grey bar) and $30{ }^{\circ} \mathrm{C}$ (blank bar). No production was recorded at $37^{\circ} \mathrm{C}$. Growth kinetics is reported as squares with broken lines $\left(37^{\circ} \mathrm{C}\right)$, filled diamonds $\left(30{ }^{\circ} \mathrm{C}\right)$, triangles $\left(25^{\circ} \mathrm{C}\right)$, circles $\left(20^{\circ} \mathrm{C}\right)$ and crosses $\left(15^{\circ} \mathrm{C}\right)$. Antimicrobial activity is expressed as mean $\pm \mathrm{SD}$ of three measures; asterisks indicate statistically significant results by Tukey's test $(p<0.05)$ 


\section{Discussion}

In this study, $14 \%$ of the screened $L$. plantarum displayed a bacteriocin-like antagonistic activity (data not shown). Our results demonstrated that the selected L. plantarum LpU4 strain produced a novel, plasmid-encoded bacteriocin of 4,866.7 Da. Plantaricin LpU4 was heat-resistant and insensitive to several chemicals and $\mathrm{pH}$ exposure sharing these features with several recently reported bacteriocins from $L$. plantarum strains (Todorov et al. 2011; Martinez et al. 2013; Gupta and Tiwari 2014).

Moreover, crude plantaricin LpU4 showed an increased antimicrobial activity in acidic environment: since no inhibition was shown by supernatant of cured L. plantarum LpU4 at low $\mathrm{pH}$, we suppose that higher plantaricin activity could be attributed to a better binding to the cell surface or to increased solubility and consequent higher diffusion rate in agar plates in acidic conditions, although we cannot completely discard a synergistic effect of organic acids present in the supernatant. Previously, $\mathrm{Hu}$ et al. (2013) reported the semi-purified plantaricin 163 to be more active at acidic $\mathrm{pH}$ and Zhu et al. (2014) have used preparation of plantaricin ZJ008 at pH 5 to detect the bacteriocin activity.

Plantaricin LpU4 was active against strains isolated from food and, interestingly, against several $S$. aureus with various antibiotic-resistance phenotypes including a methicillin-resistant strain (MRSA). Recently, Zhu et al. (2014)) have reported the plantaricin ZJ008 targeting an MRSA isolate. Although no definitive conclusion could be drawn about the efficacy of plantaricin LpU4 against other MRSA strains, it is interesting to notice that bacteriocin activity was not abolished by this specific MRSA phenotype. Anyway, the recovery of the anti-staphylococcal L. plantarum LpU4 from a traditional cheese is of noteworthy relevance considering that the $6.4 \%$ of all foodrelated outbreaks reported in the EU (2012) were caused by staphylococcal toxins and in $20 \%$ of the cases the food vehicle was cheese (EFSA-CDPC report, 2014). Furthermore, high $S$. aureus counts have been reported for several raw milk cheeses not only in Italy, but also worldwide (Little et al. 2007; Giammanco et al. 2011). The mode of action of $L$. plantarum bacteriocins is usually bactericidal (Todorov 2009), although a bacteriostatic effect has been reported for plantaricin C19 (Atrih et al. 2001) and plantaricin TF711 (Hernández et al. 2005). At the tested concentrations, plantaricin LpU4 displayed a bacteriostatic mode of action against high levels of cells target. The production of plantaricin LpU4 agreed with the characteristics of a primary metabolite, the unaltered activity titre until $48 \mathrm{~h}$ suggested that extracellular proteolytic enzymes able to degrade the bacteriocin were not produced massively. Similar trend has been reported for plantaricin MG (Gong et al. 2010). Maximal production was recorded in MRS 5 and was related both to a greater cellular biomass and relatively lower growth rate. Similarly, an in house buffered medium was used to improve biomass accumulation and bacteriocin production in Streptococcus salivarius NU10 (Barbour and Philip 2014). Moreover, initial $\mathrm{pH}$ values of 5.5 or 6.2 enhanced the production; likewise, culture medium at $\mathrm{pH} 5.5$ is among the factors that positively influences bacteriocin production in Lactobacillus curvatus L442 and Leuconostoc mesenteroides L124 (Mataragas et al. 2003). Relatively low temperature appears to be a relevant factor affecting the production, and antimicrobial activity was not detected when L. plantarum LpU4 was cultured at $37^{\circ} \mathrm{C}$. Detrimental effect of increased temperature on bacteriocin production has been reported for Carnobacterium maltaromaticum UAL26 (Miller and

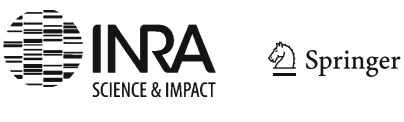


McMullen 2014). In this study, the authors propose that change in membrane fluidity due to the temperature could cause conformational changes of embedded proteins involved in bacteriocin transport with consequent alteration of their function.

On the other hand, the tested inoculum levels did not affect the ability to synthesize the bacteriocin in a liquid medium, as opposed to L. plantarum $\mathrm{C} 2$ that requires a wellestablished initial cell density to trigger the quorum-sensing mediated bacteriocin production (Rizzello et al. 2014). By these preliminary data, we can suppose that plantaricin LpU4 is not regulated by inducing peptides, however further studies about the genes encoding for this novel bacteriocin are required to confirm the assumption.

\title{
5 Conclusion
}

Based on this work, L. plantarum LpU4 as well as its purified plantaricin LpU4 could be suitable as biopreservatives in cheese. In fact, the bacteriocin activity was enhanced at acidic $\mathrm{pH}$, was not affected by $\mathrm{NaCl}$ and a remarkable production was shown when the $L$. plantarum LpU4 was cultured at $15-20^{\circ} \mathrm{C}$. Similar conditions were recorded in the core of analysed traditional cheese: the $\mathrm{pH}$ ranged from 4.8 to 5.6, the $\mathrm{NaCl}$ content was around $3 \%$ and cheese was ripened at room temperature, varying over the seasons. However, in the foodstuffs, other intrinsic factors can affect the diffusion and the efficacy of bacteriocins, as showed in an in vitro model by Blom et al. (1997). Thus, further investigations are required to evaluate the suitability of this plantaricin for use as biopreservative in cheese. The availability of an isogenic strain unable to produce the bacteriocin would be very valuable to discern the contribution of the plantaricin LpU4 to the overall antimicrobial activity of $L$. plantarum LpU4.

\begin{abstract}
Aknowledgments C. Milioni carried out her research work as $\mathrm{PhD}$ student on "Produzioni animali, Sanità e Igiene degli Alimenti nei Paesi a Clima Mediterraneo"- Pisa University. Work at IPLA-CSIC was supported by Grant BIO-2010-17414 (MINECO; Spain) to B. Martínez. Work at Istituto Zooprofilattico was funded by Ricerca Corrente LT 10/11 (Ministero della Salute, Italy) to R. Fischetti. The authors wish to tanks Ana B. Campelo for her technical assistance to isolate Lactobacillus plasmids.
\end{abstract}

Conflict of interest No conflict of interest declared.

\section{References}

Almli VL, Verbeke W, Vanhonacker F, Naes T, Hersleth M (2011) General immage and attribute perceptions of traditional food in six European countries. Food Qual Prefer 22:129-138

Atrih A, Rekhif N, Moir AJ, Lebrihi A, Lefebvre G (2001) Mode of action, purification and amino acid sequence of plantaricin $\mathrm{C} 19$, an anti-Listeria bacteriocin produced by Lactobacillus plantarum $\mathrm{C} 19$. Int $\mathrm{J}$ Food Microbiol 68:93-104

Barbour A, Philip K (2014) Variable characteristics of bacteriocin-producing Streptococcus salivarius strains isolated from Malaysian subjects. PLoS ONE 18:e100541

Blom H, Katla T, Hagen BF, Axelsson L (1997) A model assay to demonstrate how intrinsic factors affect diffusion of bacteriocins. Int J Food Microbiol 38:103-109

Caro I, Mateo J, Sandoval MH, Soto S, Garcia-Armesto MR, Castro JM (2013) Characterization of Oaxaca raw milk cheese microbiota with particular interest in Lactobacillus strains. J Dairy Sci 96:3461-3470 
Cohen SL, Chait BT (1997) Mass spectrometry of whole proteins eluted from sodium dodecyl sulfatepolyacrylamide gel electrophoresis gels. Anal Biochem 247:257-267

Cotter PD, Hill C, Ross RP (2005) Bacteriocins: developing innate immunity for food. Nat Rev Microbiol 3 : 777-788

De Pasquale I, Di Cagno R, Buchin S, De Angelis M, Gobbetti M (2014) Microbial ecology dynamics reveal a succession in the core microbiota that is involved in the ripening of pasta-filata Caciocavallo Pugliese cheese. Appl Environ Microbiol 80:6243-6255

De Vuyst L, Leroy F (2007) Bacteriocins from lactic acid bacteria: production, purification and food applications. J Mol Microbiol Biotechnol 13:194-199

EFSA (European Food Safety Authority) and ECDC (European Centre for Disease Prevention and Control) (2014) The european union summary report on trends and sources of zoonoses, zoonotic agents and foodborne outbreaks in 2012. EFSA J 12:3547

Giammanco GM, Pepe A, Aleo A, D’Agostino V, Milone S, Mammina C (2011) Microbiological quality of Pecorino Siciliano "primosale" cheese on retail sale in the street markets of Palermo, Italy. New Microbiol 34:179-185

Golic N, Cadez N, Terzic-Vidojevic A, Suranska H, Beganovic J, Lozo J, Kos B, Suskovic J, Raspor P, Topisirovic L (2013) Evaluation of lactic acid bacteria and yeast diversity in traditional white pickled and fresh soft cheeses from the mountain regions of Serbia and lowland regions of Croatia. Int $\mathrm{J}$ Food Microbiol 166:294-300

Gomori G (1946) Buffers in the range of pH 6.5 to 9.6. Proc Soc Exp Biol Med 62:33

Gong HS, Meng XC, Wang H (2010) Plantaricin MG active against Gram-negative bacteria produced by Lactobacillus plantarum KLDS1.0391 isolated from "Jiaoke", a traditional fermented cream from China. Food Control 21:89-96

Gupta A, Tiwari SK (2014) Plantaricin LD1: a bacteriocin produced by food isolate of Lactobacillus plantarum LD1. Appl Biochem Biotechnol 172:3354-3362

Hernández D, Cardell E, Zárate V (2005) Antimicrobial activity of lactic acid bacteria isolated from Tenerife cheese: initial characterization of plantaricin TF711, a bacteriocin-like substance produced by Lactobacillus plantarum TF711. J Appl Microbiol 99:77-84

Hu M, Zhao H, Zhang C, Yu J, Lu Z (2013) Purification and characterization of plantaricin 163, a novel bacteriocin produced by Lactobacillus plantarum 163 isolated from traditional Chinese fermented vegetables. J Agric Food Chem 61:11676-11682

Lavilla-Lerma L, Perez-Pulido R, Martinez-Bueno M, Maqueda M, Valdivia E (2013) Characterization of functional, safety, and gut survival related characteristics of Lactobacillus strains isolated from farmhouse goat's milk cheeses. Int J Food Microbiol 163:136-145

Little CL, Rhoades JR, Sagoo SK, Harris J, Greenwood M, Mithani V, Grant K, McLauchlin J (2007) Microbiological quality of retail cheeses made from raw, thermized or pasteurized milk in the UK. J Food Microbiol 25:304-312

Martinez RC, Wachsman M, Torres NI, Leblanc JG, Todorov SD, Franco BD (2013) Biochemical, antimicrobial and molecular characterization of a noncytotoxic bacteriocin produced by Lactobacillus plantarum ST71KS. Food Microbiol 34:376-381

Mataragas M, Metaxopoulos J, Galiotou M, Drosinos EH (2003) Influence of pH and temperature on growth and bacteriocin production by Leuconostoc mesenteroides L124 and Lactobacillus curvatus L442. Meat Sci 64:265-271

Miller P, McMullen L (2014) Mechanism for temperature-dependent production of piscicolin 126. Microbiology 160:1670-1678

Mills S, Serrano LM, Griffin C, O’Connor PM, Schaad G, Bruining C, Hill C, Ross RP, Meijer WC (2011) Inhibitory activity of Lactobacillus plantarum LMG P-26358 against Listeria innocua when used as an adjunct starter in the manufacture of cheese. Microb Cell Factories 10:S7

Montel MC, Buchin S, Mallet A, Delbes-Paus C, Vuitton DA, Desmasures N, Berthier F (2014) Traditional cheeses: rich and diverse microbiota with associated benefits. Int J Food Microbiol 177:136-154

O'Sullivan D, Klaenhammer TR (1993) Rapid mini-prep isolation of high-quality plasmid DNA from Lactococcus and Lactobacillus spp. Appl Environ Microbiol 59:2730-2733

Pieniak Z, Verbeke W, Vanhonacker F, Guerrero L, Hersleth M (2009) Association between traditional food consumption and motives for food choice in six European countries. Appetite 53:101-108

Rizzello CG, Filannino P, Di Cagno R, Calasso M, Gobbetti M (2014) Quorum-sensing regulation of constitutive plantaricin by Lactobacillus plantarum strains under a model system for vegetables and fruits. Appl Environ Microbiol 80:777-787

Ruiz-Barba JL, Piard JC, Jimenez-Diaz R (1991) Plasmid profiles and curing of plasmids in Lactobacillus plantarum strains isolated from green olive fermentations. J Appl Bacteriol 71:417-421

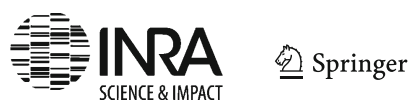


Schagger H, Von Jagow G (1987) Tricine-sodium dodecyl sulfate-polyacrylamide gel electrophoresis for the separation of proteins in the range from 1 to $100 \mathrm{kDa}$. Anal Biochem 166:368-379

Todorov SD (2009) Bacteriocins from Lactobacillus plantarum - production, genetic organization and mode of action. Braz J Microbiol 40:209-221

Todorov SD, Prévost H, Lebois M, Dousset X, LeBlanc JG, Franco BD (2011) Bacteriocinogenic Lactobacillus plantarum ST16Pa isolated from papaya (Carica papaya) - from isolation to application: characterization of a bacteriocin. Food Res Int 44:1351-1363

Torriani S, Felis GE, Dellaglio F (2001) Differentiation of Lactobacillus plantarum, L. pentosus, and L. paraplantarum by recA gene sequence analysis and multiplex PCR assay with recA gene-derived primers. Appl Environ Microbiol 67:3450-3454

Van Reenen CA, Dicks LM, Chikindas ML (1998) Isolation, purification and partial characterization of plantaricin 423, a bacteriocin produced by Lactobacillus plantarum. J Appl Microbiol 84:1131-1137

Zhu X, Zhao Y, Sun Y, Gu Q (2014) Purification and characterisation of plantaricin ZJ008, a novel bacteriocin against Staphylococcus spp. from Lactobacillus plantarum ZJ008. Food Chem 165:216-223 